\title{
Adhesion and proliferation of adipose derived mesenchymal stromal cells on chitosan scaffolds with different degree of deacetylation
}

\author{
O. Yu. Rogulska1, Yu. O. Petrenkoํㅜ, O. V. Kalinkevich ${ }^{2}$,
} A. N. Kalinkevich ${ }^{2}$, O. Yu. Petrenko'

${ }^{1}$ Institute for Problems of Cryobiology and Cryomedicine, NAS of Ukraine 23, Pereyaslavskaya Str., Kharkiv, Ukraine, 61015

${ }^{2}$ Institute for Applied Physics, NAS of Ukraine

58, Petropavlovskaya Str., Sumy, Ukraine, 40030

rog-helen@yandex.ru

\begin{abstract}
Aim. Selection of the optimal scaffold for the creation of tissue engineering constructs is a key challenge of biotechnology. In this study we investigated the biocompatibility of human adipose derived mesenchymal stromal cells (MSCs) within the three-dimensional matrices based on the chitosan with a different degree of deacetylation. Methods. MSCs were seeded on the chitosan scaffolds by a perfusion method and cultured for 7 days. The morphology, viability, metabolic activity and distribution of the cells within the matrices were analyzed. Results. The level of MSCs adhesion to the surface of the chitosan scaffolds with low degree of deacetylation (67\%) was insignificant, the cells were round and formed aggregates. In the chitosan scaffolds with a high degree of deacetylation (82\%) the cells attached to the surface of matrices, were able to spread and proliferate. Conclusions. The chitosan scaffolds with a high degree of deacetylation and the human adipose derived MSCs can be used for the creation of bioengineered structures.
\end{abstract}

Keywords: chitosan scaffolds, adipose derived mesenchymal stromal cells, tissue engineering, degree of deacetylation.

Introduction. The tissue engineering opens new possibilities for the elaboration of autologous tissue bioequivalents based on the scaffolds of natural or synthetic origin, seeded with the patient's cells [1]. The most promising cellular component of bioengineering tissues is the mesenchymal stromal cells (MSC) due to their ability to in vitro expanse and undergo the directed multilineage differentiation [2].

The adipose tissue is an alternative source of MSC similar to the bone marrow; its advantages are a high content of the progenitor cells of the mesenchymal lines and a possibility of their obtaining in the amounts, sufficient for the transplantation, with the minimal painfulness of tissue retrieval [3].

(C) Institute of Molecular Biology and Genetics, NAS of Ukraine, 2014
The key task in the elaboration of bioengineering constructions is the selection of the most suitable materials and three-dimensional scaffolds, created on their basis, which would allow the realization of the main functional characteristics of MSC in case of three-dimensional cultivation. Due to the natural origin and chemical structure, similar to the extracellular matrix, the polysaccharides attract a considerable attention in the elaboration of three-dimensional scaffolds [4]. Chitin is one of the most abundant polysaccharides on earth; it is a part of the cellular wall of some fungi, the exoskeleton of insects, mussels, crustaceans and sponges [5]. Chitosan - a deacetylated derivative of chitin - contains the links of 2-amino-2-deoxy-glucopyranose and some 2acetamido-2-deoxy-glucopyranose rings; herewith the percentage of the former in the polymer defines the de- 
gree of its deacetylation (DDA). Chitosan exhibits the immunomodulating, bactericidal, wound-healing, and haemostatic activities [6,7]. The degradation of chitosan in vivo occurs due to the action of lysozyme $(1,4-\mathrm{N}$-acetylmuramidase, EC 3.2.1.17), which is present in the excretions of lacrimal glands, eardrum, respiratory and gastrointestinal tract as well as in lymphocytes, granules of monocytes and macrophages. The glucosamines, the endproducts of chitosan disintegration, are neither toxic nor immunogenic [8].

The prospectivity of chitosan as a biomaterial for tissue engineering is conditioned by the possibility of forming three-dimensional structures of different forms on its basis (from microspheres and gels to fibrous and porous matrices) [9] as well as the possibility of modifying chitosan scaffolds via the introduction of additional compounds (hydroxylapatite, collagen, cellulose, etc.) $[9,10]$. The mechanic and biological properties of the chitosan matrices are considerably dependent on the molecular mass and deacetylation degree of the polysaccharide. It is known that the DDA of the chitosan scaffolds has a considerable effect on the attachment and morphology of human dermal fibroblasts and keratinocytes [11], rat bone marrow stromal cells [12], murine embryonal fibroblasts of NIH/3T3 line [13]. Amaral et al. [14] demonstrated that the increase in the DDA of the chitosan scaffolds by $71-95 \%$ led to the increase in the adhesion of the human osteosarcoma cells, line MG-63, to the matrices in direct proportion whereas the cells on the scaffolds with a low DDA $(<70 \%)$ neither spread nor proliferated. At the same time the adhesion and proliferation of the human adipose derived mesenchymal stromal cells on the chitosan matrices with different DDA were not investigated.

The morphological features, metabolic activity and distribution of the adipose derived MSC during the cultivation in the three-dimensional matrices on the basis of the crab shell chitosan with different degrees of deacetylation are considered in the paper.

Materials and methods. The production of three-dimensional scaffolds on the basis of chitosan. Two variants of porous three-dimensional scaffolds were used:

1. The porous scaffold (PS) on the basis of the commercial chitosan preparation from the crab shell with the deacetylation degree of $82 \%$ (PSC-82) (Mm $=200$ kDa, «CJSC Bioprogress», Russian Federation);
2. PSs on the basis of the crab shell chitosan with the deacetylation degree of $67 \%(\mathrm{PSC}-67)(\mathrm{Mm}=200 \mathrm{kDa})$, obtained by PhD A. M. Skliar (Sumy State Teacher's Training University named after A. S. Makarenko).

The porous spongy scaffolds were obtained by freeze-drying $2 \%$ chitosan solution, diluted with $1 \%$ vinegar acid. The method of coprecipitation of chitosan and the vinegar acid in $1.25 \mathrm{M} \mathrm{NaOH}$ with subsequent freeze-drying of the obtained gel was used to form the threedimensional scaffolds. The obtained materials were used to produce discs (diameter $4 \mathrm{~mm}$, thickness $2 \mathrm{~mm}$ ) using the Biopsy punch («Stiefel», Germany).

The research on the physical and chemical properties of the chitosan-based scaffolds: T h e i $\mathrm{n} f \mathrm{ra} \mathrm{red}$ $\mathrm{s} p$ e $\mathrm{ctr}$ a of the materials were obtained using the infrared spectrometer Spectrum One («Perkin Elmer», USA). Prior to the measurements the samples were mixed with $\mathrm{KBr}$ («Sigma-Aldrich», USA) and pressed into a solid tablet.

To study the structural specificities of the obtained three-dimensional matrices we conducted gold sputtering of the cross section in the vacuum universal post (VUP-5) with subsequent visualization of the surface using the scanning electron microscope REM102 («JSC Selmi», Ukraine).

The obtaining and cultivation of the adipose derived $M S C$. The adipose tissue was obtained in the course of lipectomy of adult patients in compliance with the recommendations of the World Medical Association's Declaration of Helsinki on Ethical Principles for Medical Research Involving Human Subjects and the requirements of the Bioethics Commission of the Institute for Problems of Cryobiology and Cryomedicine of the NAS of Ukraine after obtaining the written informed consent of the donors.

The adipose derived MSC were obtained according to the previously described method [15]. After that the solution of collagenase type II («Sigma», USA) was introduced in the ratio 1:3 into the adipose tissue fragments, and their suspension was incubated for $1 \mathrm{~h}$ at 37 ${ }^{\circ} \mathrm{C}$ with constant shaking at $200 \mathrm{rpm}$. The obtained suspension was centrifuged at $1000 \mathrm{rpm}$ for $20 \mathrm{~min}$. The precipitate was resuspended in $10 \mathrm{ml}$ of Hank's solution and filtered through the blood substitutes transfusion set. The detritus-free suspension was centrifuged at $1500 \mathrm{rpm}$ for $10 \mathrm{~min}$. The obtained precipitate was a 
stromal-vascular fraction of the adipose tissue, containing MSC.

The cultivation of MSC was conducted in $\alpha$-MEM medium («Sigma»), complemented with $10 \%$ fetal bovine serum («PAA», Austria), $2 \mathrm{mM}$ L-glutamine, $50 \mathrm{u} /$ $\mathrm{ml}$ penicillin and $50 \mu \mathrm{g} / \mathrm{ml}$ streptomycin at $37^{\circ} \mathrm{C}, 5 \%$ $\mathrm{CO}_{2}$ and $95 \%$ humidity. After reaching $70 \%$ confluence the culture was passaged by the standard method using the solution of trypsin $(0.25 \%)$ and versene $(0.05 \%)$ in the ratio $1: 4$.

The suspension of the unattached cells was seeded in the ratio $1: 3$. The cells of the $4^{\text {th }}$ and $5^{\text {th }}$ passages were used in the research.

The seeding of scaffolds. Prior to the seeding the chitosan discs were placed in $70 \%$ ethyl alcohol for $24 \mathrm{~h}$ with subsequent washing in Hank's solution. The seeding of scaffolds was conducted by the perfusion method, previously elaborated in our laboratory [16]. The procedure required two $1 \mathrm{ml}$ syringes, connected by the elastic plastic tube. One syringe contained the chitosan scaffold and the other syringe had $300 \mu 1$ of the cell suspension $\left(1-1.2 \cdot 10^{6}\right.$ cells $\left./ \mathrm{ml}\right)$; the successive reciprocating movements of the plungers were used for slow saturation of the cells. Then the constructions with the cells were incubated in the syringe for $3 \mathrm{~h}$ at $37^{\circ} \mathrm{C}$, and transferred into the well of the 24-well plate, containing $1 \mathrm{ml}$ of the cultivation medium.

The estimation of the metabolic activity of MSC using Alamar Blue. The Alamar Blue (AB, «Serotec», Germany), which reflects an integral level of the redox processes in cells, was used to estimate the metabolic activity of MSC, seeded into the three-dimensional scaffolds. For this purpose after $24 \mathrm{~h}$ of the cultivation the matrices, seeded with the cells, were transferred to the 24well plate with the cultivation medium, containing $10 \%$ $\mathrm{AB}$, and incubated in these conditions for $3 \mathrm{~h}$ at $37^{\circ} \mathrm{C}$. Then the medium was isolated to determine the level of $\mathrm{AB}$ reduction using the tablet spectrofluorometer Tecan GENios (Austria) with the wave of excitation of $550 \mathrm{~nm}$ and the wave of emission of $590 \mathrm{~nm}$. The data were presented as the average value of the ratio of the experiment (matrices with the cells) and the control (matrices without the cells) samples and expressed in the form of the relative fluorescence units (RFU). The level of $A B$ restoration was determined in the similar way after 7 days of cultivation.
The estimation of the morphology and distribution of the viable cells in the scaffolds. The biomicroscopy and the analysis of the azure and eosin stained preparations of cell cultures were conducted using the CETI inverted-stage microscope (Belgium), equipped with the Nikon CoolPix 4500 digital camera. The MTT indicator was used in the visualization and integral estimation of MSC distribution in the scaffolds. The principle of its work is based on the ability of the mitochondrial dehydrogenases to restore the yellow salt of 3-[4,5-dimethylthiazole-2-yl]-2,5-diphenyltetrazolium bromide (MTT) to the insoluble crystals of dark purple formazan, accumulated in the cytoplasm of the living cells. For providing MTT-test, on the $7^{\text {th }}$ day of the cultivation the scaffolds, seeded with the cells, were incubated in the medium, complemented with MTT solution («Sigma», 5 $\mathrm{mg} / \mathrm{ml}$ ) for $3 \mathrm{~h}$ at $37^{\circ} \mathrm{C}$. Then the medium was removed and the scaffolds were transferred into Hank's colorless saline solution and investigated with the MBS-9 stereomicroscope (USSR).

The statistical processing. The estimation of the normality of the obtained results was conducted using Shapiro-Wilk test. As the data distribution differed from the normal one, they were expressed in the form of the median and percentiles ( 25 and 75 ). The estimation of differences between samplings was conducted using OneWay ANOVA test and Kruskal-Wallis test. The results were deemed significantly different at $\mathrm{p}<0.05$.

Results and discussion. The research on the chitosan-containing scaffolds (67 and $82 \%$ DDA) using the infrared spectroscopy method demonstrated that the absorption bands $-2924,1318$ and $1153 \mathrm{~cm}^{-1}$ (Fig. 1) cor-

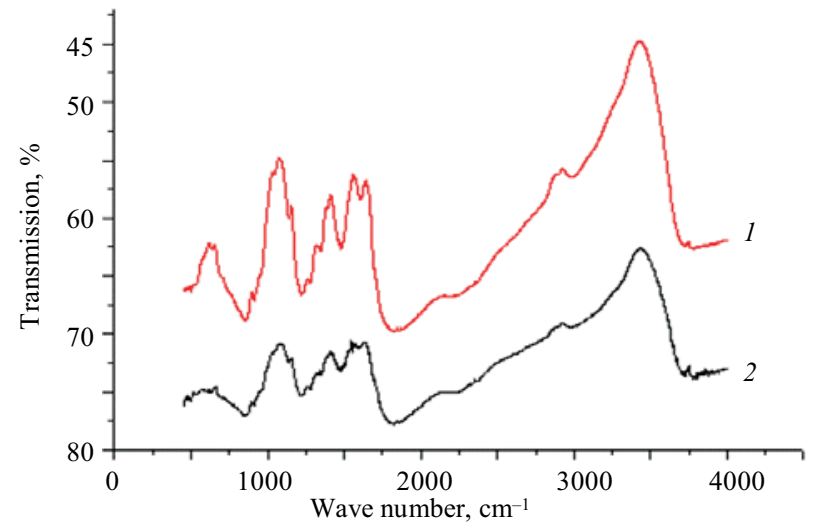

Fig. 1. IR-spectra of the chitosan scaffolds: 1 - PSC-82; 2 - PSC-67 
respond to chitosan. No significant changes in the chitosan structure occurred during the formation of the threedimensional matrices.

The evaluation of structural features of the three-dimensional matrices with REM showed that regardless of the external similarity of the obtained scaffolds, their microarchitecture was considerably different depending on the deacetylation degree of chitosan (Fig. 2).

For instance, the structure of PSC-82 (Fig. 2, $A$ ) was less dense, contained a considerable amount of pores, the walls of which were formed with thinner threads compared with PSC-67 (Fig. 2, B).

The chitosan-based matrices were seeded with the human adipose derived MSC of passages 4-5 in the concentration of $3 \cdot 10^{5}$ cells/scaffold using the perfusion method. The viability and metabolic activity of the cells within the sponges were estimated on the $1^{\text {st }}$ and $7^{\text {th }}$ days of cultivation using AB-test (Fig. 3). Depending on the type of the scaffold the fluorescence values of the reduced $\mathrm{AB}$ were considerably different as early as $24 \mathrm{~h}$ after the cultivation.

The fluorescence intensity of the $\mathrm{AB}$ reduction product in the PSC-67 group was 0.9943 RFU and did not differ from the control (background) values. Conversely, in PSC-82 this index was twice higher and amounted to $1.9507 \mathrm{RFU}$. The data, obtained on the $1^{\text {st }}$ day of the cultivation, are likely to reflect the adhesive properties of the three-dimensional matrices. It is known that the realization of the biological potential of the substrate-dependent cells, including MSC, directly depends on their adhesion and the degree of spreading on the substrate, therefore, a low level of $\mathrm{AB}$ reduction in the PSC67 group may testify to the absence of full-scale adhesion of the cells to the matrix surfaces of this type. Indeed, the microscopy research demonstrated that MSC on the surface of PSC-67 pores retained their round form. In the PSC-82 group the cells attached and spread on the surface of the chitosan matrices which explains the higher level of fluorescence for the reduced AB.

The level of $A B$ reduction did not change with the further three-dimensional cultivation of the adipose derived MSC in PSC-67. At the same time the fluorescence intensity of $\mathrm{AB}$ during the cultivation of the adipose derived MSC in PSC- 82 increased by $23 \%$ on the $7^{\text {th }}$ day relative to one day of the cultivation. Taking into consideration the fact that $\mathrm{AB}$ is an integral index of the
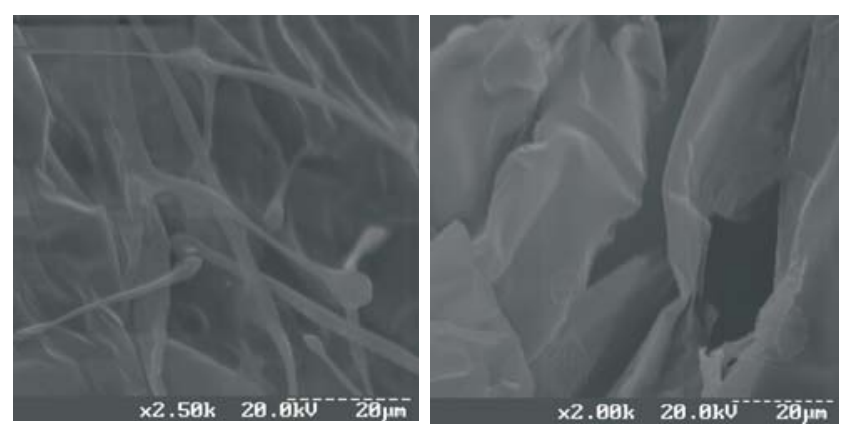

Fig. 2. REM of scaffolds on the basis of chitosan: $A-$ PSC- $82 ; B-$ PSC-67

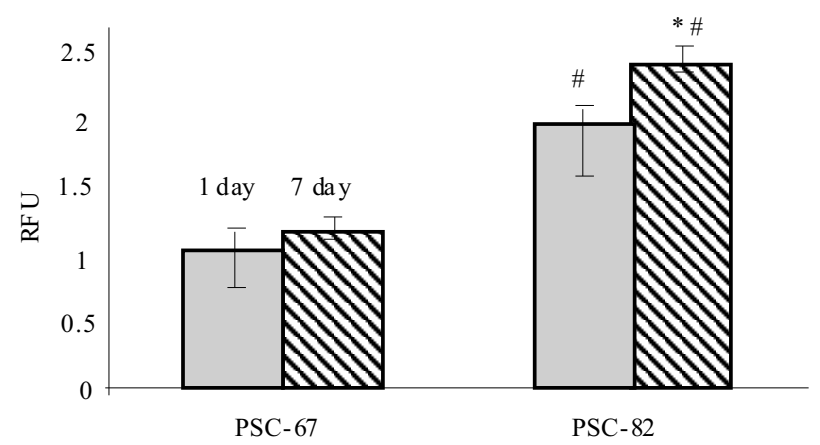

Fig. 3. The metabolic activity of MSC at the three-dimensional cultivation in the chitosan scaffolds, estimated by the level of $\mathrm{AB}$ reduction; ${ }^{*} \mathrm{p}<0.05$ relative to day $1 ; \# \mathrm{p}<0.05$ relative to PSC-67

activity of redox enzymes, the significant increase in the level of its reduction in the process of cultivation testifies to the cells retaining their metabolic activity and also is an indirect reflection of their proliferation during the three-dimensional cultivation.

The data obtained were proven during the research on the MSC distribution in the matrices using the MTT metabolic activity index for the cells (Fig. 4). It was established that MSC, seeded in PSC-67, were not spread but rather formed the aggregates of different sizes on the matrix surface (Fig. 4, A). Conversely, the adipose derived MSC, cultivated in PSC-82, were distributed along the whole volume of the scaffold, which was proven by the even dark purple coloring (Fig. 4, B).

The microscopic research demonstrated that the cells, seeded in PSC-82, were well spread and had the typical fibroblast-like morphology (Fig. 5).

The results of this work demonstrate that the adhesion, morphology and proliferation of the adipose derived MSC are considerably dependent on the specific properties of the matrices, produced of the crab shell chi- 

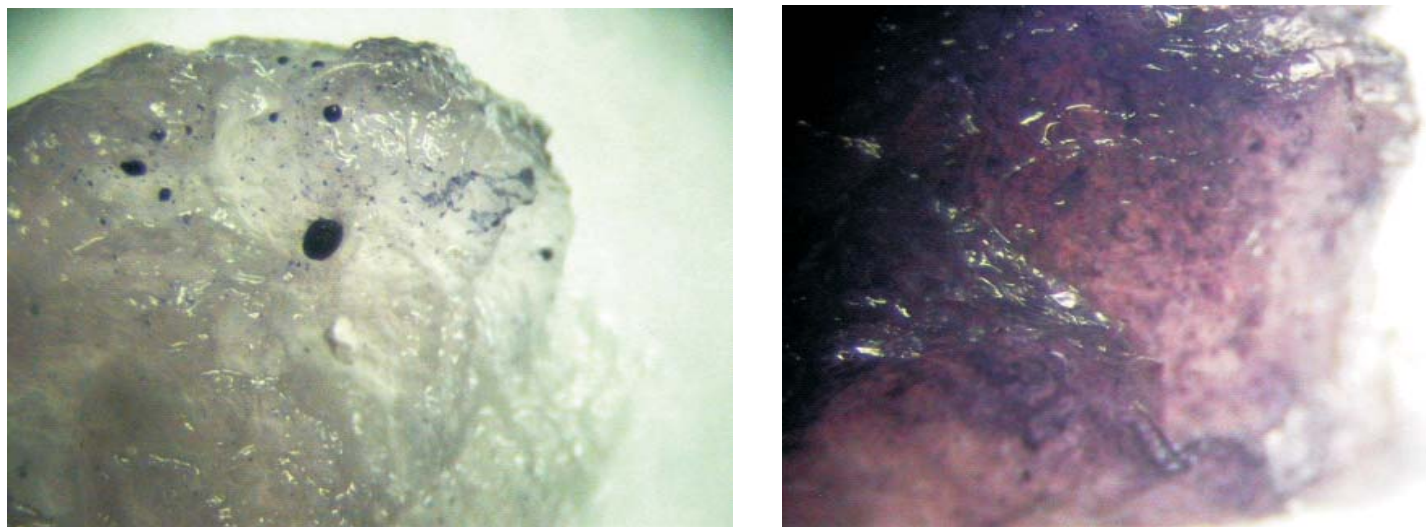

Fig. 4. The MSC distribution in the scaffolds after 7 days of cultivation: $A-$ PSC67; $B$ - PSC-82; MTT- test. $\times 10$

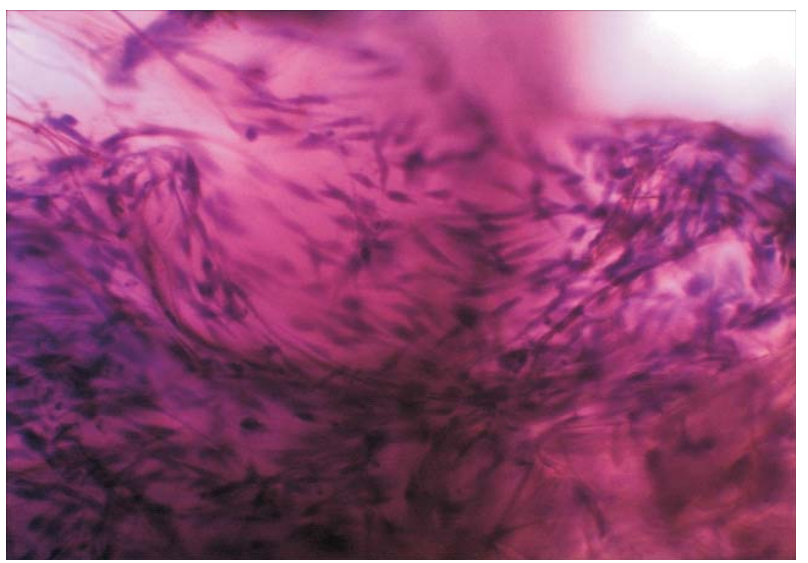

Fig. 5. The MSC morphology in PSC-82, 7 days of cultivation. The staining with azure and eosin. $\times 100$

tosan. The properties of the chitosan scaffolds are known to depend on the molecular mass, the deacetylation degree, the crystallinity index for chitosan and the method of sample preparation $[7,9]$. The key parameter, determining the solubility, viscosity, electrostatic indices and biodegradation rate of chitosan, is the deacetylation degree $[11-14,17]$.

In their works Amaral et al. [12] demonstrated that the murine embryonic fibroblasts of $\mathrm{NIH} / 3 \mathrm{~T} 3$ line were attached and spread with the formation of long filopodia and numerous intercellular contacts on chitosan scaffolds with a high DDA (85-90 \%) but they had a round form and formed spheroid aggregates on the matrices with a lower DDA (75-85\%). In this research the adipose derived MSC also retained their round form during the three-dimensional cultivation in vitro in PSC-67, but they were characterized by their normal fibroblast-like morphology in the chitosan scaffolds with the DDA $82 \%$. These discrepancies between the results obtained by Amaral et al. [12] and our data may be conditioned by both the source of chitosan (the squid shell in the first case and the crab shell - in the second one) and the specificities of the cultivated cells. Notably the structure of PSC-82 allowed for the even full-blast spreading of the adipose derived MSC in the scaffold, whereas in PSC67 the cells formed large spherical aggregates on the surface.

Chatel et et al. [11] demonstrated that the adhesion and growth of cells on the chitosan matrices depend on the DDA of the polysaccharide and directly on the type of the cells. For instance, the keratinocytes were better attached and proliferated on the surface of the chitosan scaffolds with a high DDA ( $\geq 85 \%$ ), whereas the fibroblasts were not capable of any proliferation. The results of our investigations demonstrated that the adipose derived MSC were capable of both adhesion and the active proliferation in PSC-82. In case of PSC-67 the degree of cell adhesion to the surface of sponges was decreased which had a negative effect on the metabolic activity and proliferative capability of MSC. These results are in agreement with the data, obtained for the murine embryonic fibroblasts, line NIH/3T3 [17], which demonstrated that the biocompatibility of chitosan increases with the increase of the DDA. The chitosan with a higher deacetylation degree might have more cation sites, which provide for the attachment of the cells with negatively charged surface via the non-specific electrostatic interaction.

Conclusions. The data obtained confirm the prospectivity of the application of chitosan sponges with a low molecular mass and a high DDA as the scaffolds for elaborating some bioengineering constructs, used in the pharmacology as well as in the reconstructive and cosmetic plastic surgery. 
Адгезія та проліферація мезенхімальних стромальних клітин жирової тканини у хітозанових носіях з різним ступенем деацетилювання

О. Ю. Рогульська, Ю. О. Петренко, О. В. Калінкевич, О. М. Калінкевич, О. Ю. Петренко

\section{Резюме}

Вибір оптимального носія клітин для створення тканинно-інженерних конструкцій - ключова проблема сучасної біотехнологіі. Мета. Дослідити біосумісність мезенхімальних стромальних клітин (МСК) жирової тканини людини з об' ємними матрицями на основі хітозану з різним ступенем деацетилювання. Методи. Xiтозанові носії заселяли МСК перфузійним методом і культивували протягом 7 діб. Проводили аналіз морфологічних особливостей, життєздатності, метаболічної активності та розподілу клітин у матрицях. Результати. Рівень адгезї МСК до поверхні хітозанових носіїв з низьким ступенем деачетилювання (67\%) був незначним, клітини мали округлу форму та формували агрегати. У губках на основі хітозану з високим ступенем деацетилювання (82\%) клітини прикріплювались до поверхні носія, розпластувались $і$ були здатними до проліферачії. Висновки. Отримані результати свідчать про перспективність використання хітозанових носїв з високим ступенем деацетилювання та МСК жирової тканини людини для створення біоінженерних конструкиій.

Ключові слова: хітозанові носї̈, мезенхімальні стромальні клітини жирової тканини, тканинна інженерія, ступінь деацетилювання.

Адгезия и пролиферация мезенхимальных стромальных клеток жировой ткани в хитозановых носителях с разной степенью деацетилирования

Е. Ю. Рогульская, Ю. А. Петренко, О. В. Калинкевич, А. Н. Калинкевич, А. Ю. Петренко

\section{Резюме}

Выбор оптимального носителя клеток для создания тканеинженерных конструкиий является ключевой проблемой современной биотехнологии. Цель. Исследовать биосовместимость мезенхимальных стромальных клеток (МСК) жировой ткани человека с объемными матрицами на основе хитозана с разной степенью деацетилирования. Методы. Хитозановые носители заселяли МСК перфузионным методом и культивировали в течение 7 суток. Проводили анализ морфологических особенностей, жизнеспособности, метаболической активности и распределения клеток в матpицах. Результаты. Уровень адгезии МСК к поверхности хитозановых носителей с низкой степенью деацетилирования (67\%) был незначительным, клетки имели округлую форму и формировали агрегаты. В губках на основе хитозана с высокой степенью деачетилирования (82\%) клетки прикреплялись к поверхности носителя, распластьвались и пролиферировали в прочессе культивирования. Выводы. Полученные результаты свидетельствует о перспективности использования хитозановых носителей с высокой степенью деацетилирования и МСК жировой ткани человека для создания биоинженерных конструкиий.

Ключевые слова: хитозановые носители, мезенхимальные стромальные клетки жировой ткани, тканевая инженерия, степень деацетилирования.

\section{REFERENCES}

1. Hin TS. Engineering materials for biomedical application. World Scientific Publishing Co. Pte. Ltd. 2004; 350 p.

2. Pittenger MF, Mackay AM, Beck SC, Jaiswal RK, Douglas R, Mosca JD, Moorman MA, Simonetti DW, Craig S, Marshak DR. Multilineage potential of adult human mesenchymal stem cells. Science. 1999; 284(5411):143-7.

3. Zuk PA, Zhu M, Ashjian P, De Ugarte DA, Huang JI, Mizuno H, Alfonso ZC, Fraser JK, Benhaim P, Hedrick MH. Human adipose tissue is a source of multipotent stem cells. Mol Biol Cell. 2002; 13(12):4279-95.

4. Shoichet MS. Polymer scaffolds for biomaterials applications. Macromolecules. 2010; 43(2):581-91.

5. Khoushab F, Yamabhai M. Chitin research revisited. Mar Drugs. 2010; 8(7):1988-2012.

6. Ravi Kumar R. A review of chitin and chitosan applications. React Funct Polym. 2000; 46(1):1-27.

7. Mikhailov GM, Lebedeva MF, Pinaev GP, Iudintseva NM, Blinova MI, Panarin EF. New woven matrix made of resorbed natural chitin polysaccharide for culturing and transplantation of human skin cells. Cell Transpl and Tissue Eng. 2006; 1(4):56-61.

8. Heinemann C, Heinemann S, Bernhardt A, Lode A, Worch H, Hanke T. In vitro osteoclastogenesis on textile chitosan scaffold. Eur Cell Mater. 2010; 19:96-106.

9. Costa-Pinto AR, Reis RL, Neves NM. Scaffolds based bone tissue engineering: the role of chitosan. Tissue Eng Part B Rev. 2011; 17(5):331-47.

10. Madhumathi K, Binulal NS, Nagahama H, Tamura H, Shalumon KT, Selvamurugan N, Nair SV, Jayakumar R. Preparation and characterization of novel beta-chitin-hydroxyapatite composite membranes for tissue engineering applications. Int $J$ Biol Macromol. 2009; 44(1):1-5.

11. Chatelet C, Damour O, Domard A. Influence of the degree of acetylation on some biological properties of chitosan films. Biomaterials. 2001; 22(3):261-8.

12. Amaral IF, Lamghari M, Sousa SR, Sampaio P, Barbosa MA. Rat bone marrow stromal cell osteogenic differentiation and fibronectin adsorption on chitosan membranes: the effect of the degree of acetylation. J Biomed Mater Res A. 2005; 75(2):387-97.

13. Nwe N, Furuike T, Tamura H. The mechanical and biological properties of chitosan scaffolds for tissue regeneration templates are significantly enhanced by chitosan from Gongronella butleri. Materials. 2009; 2(2):374-98.

14. Amaral IF, Sampaio P, Barbosa MA. Three-dimensional culture of human osteoblastic cells in chitosan sponges: the effect of the degree of acetylation. J Biomed Mater Res A. 2006; 76(2):335-46.

15. Petrenko AYu, Petrenko YuA, Skorobogatova NG, Zhylikov OA, Pravdyuk AI, Mazur SP, Gorokhova NA, Grishchuk VP, Volkova NA. Adipose tissue stromal progenitor cells: isolation, phenotypic and differentiation properties during monolayer cultivation. J. Natl Acad. of Med. Sci. of Ukr. 2008; 14(2):354-6.

16. Petrenko YA, Ivanov RV, Lozinsky VI, Petrenko AY. Comparison of the methods for seeding human bone marrow mesenchymal stem cells to macroporous alginate cryogel carriers. Bull Exp Biol Med. 2011; 150(4):543-6.

17. Seda Tigli R, Karakecili A, Gumusderelioglu M. In vitro characterization of chitosan scaffolds: influence of composition and deacetylation degree. J Mater Sci Mater Med. 2007; 18(9):1665-74. 